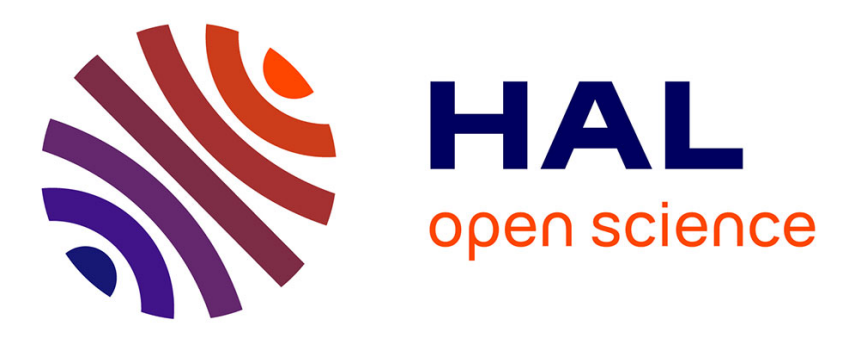

\title{
Origin and Conceptual Evolution of the Term tahș̣ịs in Arabic Grammar
}

\author{
Manuel Sartori
}

\section{To cite this version:}

Manuel Sartori. Origin and Conceptual Evolution of the Term tahșịs in Arabic Grammar. Georgine Ayoub; Kees Versteegh. The Foundations of Arabic Linguistics III. The Development of a Tradition: Continuity and Change, 94, Brill, pp.203-228, 2018, Studies in Semitic Languages and Linguistics," 978-90-04-36521-6. 10.1163/9789004365216_012 . hal-03088791

\section{HAL Id: hal-03088791 https://hal.science/hal-03088791}

Submitted on 26 Jan 2021

HAL is a multi-disciplinary open access archive for the deposit and dissemination of scientific research documents, whether they are published or not. The documents may come from teaching and research institutions in France or abroad, or from public or private research centers.
L'archive ouverte pluridisciplinaire HAL, est destinée au dépôt et à la diffusion de documents scientifiques de niveau recherche, publiés ou non, émanant des établissements d'enseignement et de recherche français ou étrangers, des laboratoires publics ou privés. 


\title{
The Foundations of \\ Arabic Linguistics III
}

\author{
The Development of a Tradition: \\ Continuity and Change
}

Edited by

Georgine Ayoub

Kees Versteegh

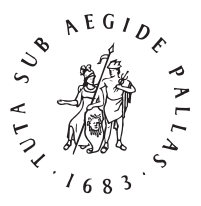

B R I L L

LEIDEN | BOSTON

For use by the Author only | (C) 2018 Koninklijke Brill NV 


\section{Contents}

List of Contributors VII

Introduction 1

Georgine Ayoub and Kees Versteegh

Case and Reference

The Theory of mā yanșarif wa-mā lā yanșarif in Sïbawayhi's Kitāb 11 Georgine Ayoub

The Grammatical and Lexicographical Traditions

Mutual Foundations, Divergent Paths of Development $\quad 50$

Ramzi Baalbaki

A Twelfth Century League Table of Arab Grammarians $\quad 76$

Michael G. Carter

Blind Spots in Raḍī l-Dīn al-'Astarābādī’s Grammar of Numerals 96 Jean N. Druel

Syntax, Semantics, and Pragmatics in al-Sīrāfī and Ibn Sīnā 115

Manuela E.B. Giolfo and Wilfrid Hodges

Early Pedagogical Grammars of Arabic 146

Almog Kasher

What is Meant by al-ḥäl al-muqaddara? $\quad 167$

Aryeh Levin

Demonstratives in Sībawayhi's Kitāb $\quad 178$

Arik Sadan

How Have the Descriptions of tahdīir Changed? 190

Haruko Sakaedani

For use by the Author only | (C) 2018 Koninklijke Brill NV 
Origin and Conceptual Evolution of the Term tahșiș in Arabic

Grammar 203

Manuel Sartori

The Classification of the Verb in the Arab Grammatical Tradition

From Sïbawayhi to al-Jurjānī 229

Zeinab A. Taha

Learning Arabic in the Islamic World 245

Kees Versteegh

Index $\quad 269$ 


\title{
Origin and Conceptual Evolution of the Term tahșīs in Arabic Grammar*
}

\author{
Manuel Sartori
}

Introduction: Tahṣiș, a Forgotten Term?

The third volume of The foundations of Arabic linguistics, subtitled The development of a tradition: Continuity and change, constitutes an appropriate framework for showing that not everything is said with the Kitāb of Sỉbawayhi (d. 18o/796?). It is in this context that I undertake the archeology of the technical term tahșiș, commonly rendered as 'particularization', whose history and evolution within the Arabic grammatical tradition I trace. Ibn al-Hājib (d. 646/ 1249) first drew my attention to this category, of which I had never heard in my Arabic studies.

Tahșịs remains a little-known term. First of all, it is not treated as a separate category in the Classical Arabic grammars, ${ }^{1}$ which do not reserve a special chapter to it. Moreover, the term is almost completely absent from Orientalist grammars, which simply ignore it as such (Silvestre de Sacy 1831; Forbes 1863; Palmer 1874; Socin 1885; Donat Vernier 1891; Howell 1911; Fleisch 1961, 1979; Blachère and Gaudefroy-Demombynes 1975). Finally, contrary to expectation, neither the Encyclopaedia of Islam, nor the Encyclopedia of Arabic language and linguistics devote an entry to tahșiș.

When the term or the concept denoted by it are mentioned, it is usually in passing. Thus, in the Encyclopedia of Arabic language and linguistics, Hoyt (2009:316b) mentions the phenomenon in the entry "Specificity", but does not give its name, while the entry "I $\underline{d a} f a$ " incidentally mentions the phenomenon by citing ihtiṣạs (cf. Ryding and Versteegh 2007:295b). Likewise, in the second edition of the Encyclopaedia of Islam, tahșiș is quoted incidentally in the entries

* In quotes, I keep the author's transliteration. I thank Michael Carter and Jean Druel for their remarks, which helped me to improve this article.

1 Note also that the root h-ṣ-ṣ is only used four times in the Qurān, twice for yahușșuhu bihi (2/105; 3/74), once for hāṣṣatan (8/25) and once for hasạāsatun (59/9) (cf. 'Abd al-Bāqī 1997:297). 
"iḍāfa" (Fleisch 1986:10o8b), "nat" (Troupeau 1993:1034a) and "ta'rīf" (Carter 2000:241b). Finally, Brustad (2000:21) briefly mentions it in passing.

By placing this work in the context of continuity and change, I have three objectives: i. to conduct an archeological search of the term tahșiss in Arabic grammar; ii. to trace the evolution of its conceptual content; iii. to identify its origin. First, however, we need to define the notion of tahșiss, which, given the scattered nature of the information, can only be done by a combination of sources.

\subsection{Lexical Family and Meaning of h-ṣ-s}

The term tahșiș is a verbal noun (mașdar) of what is called in the Orientalist tradition Form II fa"ala/yufa"cilu from the root h-s-ș. Form I of this verb, hașsa/yahușșu means 'to distinguish, to specify; to apply in particular to, to be characteristic of'. Of this basic verb, two derivations are frequently used, the active participle hășs and the passive participle mahșuṣs. As for the first, it should be understood either as 'peculiar, specific', opposed to 'āmm 'general,', or as 'particularizing; someone who/something which particularizes', opposed to mahșusss 'someone/something particularized, specific, specified'. The latter in turn is well known in Arabic grammar, especially to designate the specific object of praise or blame in structures involving 'af'äl al-madh wa-l-damm, the praised or blamed object being the mahșūṣ bi-l-madh 'aw bil-damm.

From this verb base some augmented stems are derived: the monotransitive Form II hașșașahu 'to particularize, to specify', which is the factitive of Form I and whose mașdar is tahșiș; a bi-transitive Form vinI, direct and prepositional, ihtașsahu bihi 'to dedicate s.th. to s.o., to confer distinction upon s.o. by s.th.', of equivalent meaning with ihtașsahu lahu; ${ }^{3}$ a monoprepositional ihtașșa bihi 'to be peculiar to; to concern, regard s.th.; to be distinguished, marked by'; a monotransitive ihtașsahu 'to take exclusive possession of' with the meaning of 'to characterize s.th.; an intransitive ihtașşa 'to distinguish one's self, to specialize', with a passive form uhtușsa ( $b i-$ ) 'to be characterized, specified (by), to become specific (to)'. Finally, from Form II a Form v is derived tahaș̣așa

2 A number of well-known works of 'uṣül al-figh contain a chapter entitled al-'āmm wa-l-hăṣṣ 'the general and the particular'.

3 Cf. Ibn al-Sarrāj, 'Ușūl I, 156. 
(bihi) 'to particularize one's self (by), to be peculiar (to)'. In the present paper I will focus mainly on tahșiș, whose precise technical meaning remains to be defined, as well as to derivatives of the root $h-s ̣$-ș, relating thereto. ${ }^{4}$

\subsection{The Grammatical Technical Meaning of tahṣiṣ among Modern Authors}

Given the scattered nature of the information about tahșiș, its definition can only be achieved by combining sources. Relying on secondary sources but also on primary (old as well as late), I shall give a first definition of tahșiș. This idealtypical definition will then be used to identify the phenomenon in Classical Arabic grammatical treatises and proceed to engage in an archeology of tahșiss. This archeology will then allow us to assess the evolution of the conceptual content of the notion.

Wright (1996:II, 198D, 199A, 26o-261D) ${ }^{5}$ assigns to tahșiș the semantic function of limiting, more specifically that of 'partial determination' ${ }^{6}$ Terminologically, tahșiss is very clearly stated to be connected with tankïr and ta'rïf. ${ }^{7}$ Contextually, tahșiss appears in conjunction with the annexing construction and, more incidentally, with the qualification. Finally, syntactically and technically, tahșiş consists i) in the annexation of an indefinite genitive ('amalu birrin), or ii) in the qualification of an indefinite noun by an adjective (rajulun karimun) or by an expression equivalent to an adjective ('amrun bi-ma'rüfin).

Unlike Wright, Reckendorf (1921:57, 193, 200, 218) does not deal with tahșiss in the chapter on annexation, but in those dealing with the adjective and with indefiniteness (tankir). Overall, the same information may be culled from Reckendorf as from Wright. Semantically, tahșịs is a 'particularization' (Beson-

4 Therefore, I will not pay attention to other technical terms, such as those of tahșiș al-illa 'cause particularization' (cf. al-Sayyid al-Šarîf, Ta'rîfät 57 and for the technical term 'illa, cf. Versteegh 2007, 2011), nor such as mahșūṣ used in the framework of the expression of praise or blame (mahṣuṣs bi-l-madḥ/damm).

5 The passages in which tahșiș occurs are in fact Wright's additions in the form of footnotes to the text of Caspari, the latter not quoting the term, neither in his Latin edition of 1844-1848, nor in the German one of 1859. Cf. Caspari (1848:221f., 250; 1859:288f., 330).

6 Goguyer (1888:208) translates the term in verse 919 of the 'Alfiyya of Ibn Mālik (d. 672/1274) as 'reserving'; in his translation of the Qațr al-nadā of Ibn Hišām al-'Anșārī (d. 761/136o), he uses 'particularization' (cf. notably Goguyer 1887:284, 286, or words from the same Latin root). The latter translation will be adopted here.

7 Note that Fleisch (1961:I, 339f.) remarks that the issue of determination and indetermination in Arabic "est difficile et jusqu' ici n'a pas reçu une élucidation suffisante", which seems to imply the existence of tahșiș. 
derung, 57), a 'quasi-determination' (nähere Bestimmung, 200), and a 'restriction' (Einschränkung, 218); it is connected with tankïr and ta'rîf.

Badī' Ya'qūb and 'Āṣ̂̀ (1987: I, 154, 367, II, 1254) are in turn the only ones, to my knowledge, to reserve an entry to tahșis in a dictionary of Arabic grammar and/or of figh al-lugia. ${ }^{8}$ In addition to the entry (I, 367$)$ where it is specifically linked to annexation, they also deal incidentally with it in entries "idâfa" (I, 154), "atf al-bayān" (II, 868) and "nat" (II, 1254). On the whole, they assign to it the same connection with tankir and ta'riff, in the same contexts, plus the explanatory apposition ('atfal-bayān).

I will end this first part with two 'late' authors: al-Sayyid al-Šarīf, i.e. 'Alī ibn Muḥammad al-Jurjānī (d. 816/1413) and Muḥammad ibn 'Aḥmad al-Širbīnī (d. 977/1570). Tahșịs is found five times in al-Sayyid al-Šarîf. In his Kitāb alta'riffät he defines this term when it has the technical sense we are interested in, as follows: "particularization among grammarians is an expression meaning the restriction of equivocity occuring in indefinite expressions like 'a learned

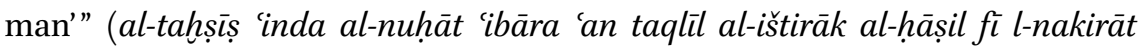
naḥwa 'rajulun 'ālimun', Ta'rî́āt 57 ).

In al-Širbīni’s commentary on the 'Ājurrūmiyya of Ibn 'Ājurrūm (d. 723/ 1323), ${ }^{9}$ tahșiss is used twice: "An undefined antecedent may occur when justified by specialization, generalization, or inversion. Specialization may be effected either by annexation [...] or by adjectival qualification" (wa-yaqa u nakira bimusawwig wa-huwa 'immā al-tahșịs 'aw al-ta'mìm 'aw al-ta'hir fa-l-awwal wahuwa l-tahșịs sawāàn 'a-kāna bi-iịāfa [...] 'aw bi-wașf, Carter 1981:376). Carter (1981:377) explains that

'specialization', taksșiss, is an intermediate level between absolute indefinition and pure definition [... and] that 'specialized' elements (i.e. qualified by adjectives, like fulukin mākirin [...]) are sufficiently defined to function as subjects on nominal sentences.

8 There is indeed no trace of it in al-Labdī (1985); Fawwāl Bābitī (1992); 'Abbās Ma'an (2001); 'Abbās Ma'an (2002); 'Ubāda (2011), nor in Marzā al-Hुāmis (2012). Only Baraké (1985:154) mentions it with the meaning of 'particularization', shared with tamyiz, which is not odd (cf. infra).

9 The editor of the text, Carter (1981:v), indicates that "in the Arabic text Ibn Ājurrūm's own words have, according to the practice of the day, been directly integrated into aš-Širbīnì's commentary, and are therefore distinguished by overlining". Occurrences of tahșịs not being highlighted, they are indeed additions made by the commentator, al-Širbīnī, to the primary text (matn). 
He notes (1981:461) that “'Specialization' is takssiss, cognate (and almost synonymous with) ik $k i s \underline{a}$ ș 'particularization' [...], in both cases denoting an intermediate stage between absolute definition and indefinition".

If we add to these data the information distilled from Gätje (1970:47, 235); Fleisch (1986:1008b); Troupeau (1993:1034a), as well as Carter's (2000:241b) comment that tahșiș is a "weaker type" of definiteness, the following definition of the phenomenon may be proposed: tahșiş is a technical term that is connected with tankir and ta'rîf. Occurring in the context of indefiniteness, it is related to several terms denoting definiteness, on which I will focus in other studies. Tahșiș is, besides, related to the grammatical categories of annexation, qualification, and explanatory apposition. Understood as 'partial determination' or 'quasi-determination', it is not only a grammatical category but also, first and foremost, a semantic category and, therefore, a pragmatic one, something well understood by the grammarian, logician and pragmatician al-'Astarābādi (d. 688/1289). ${ }^{10}$ In the following lines I will address only the syntactic aspect of tahșịṣ and its derivatives.

\section{Terminological Evolution of tahșiș}

The question to be answered now is: at what point did this term or its cognates appear in Arabic grammar with the precise meaning defined above? To do this, I have listed, in all grammatical treatises at my disposal, not only significant occurrences of tahșiss, but more generally of those terms that are derived from the root $h-s \underline{s}$ s.

Tahșịs is used once in the Kitāb of Sỉbawayhi, according to Troupeau's Lexique-index (1976:81), but only with a general meaning, not as a grammatical technical term (Kitāb I, 302). Suffice it to note that of all derivations from the root $h-s-s$, , only two occurrences are close to the technical meaning we are looking for. In both cases this concerns the quasi-technical use of Form viII ihtașsa-hu in association with specification. We will see later that a link may justly be made between tahșiș and tamyiz.". Sïbawayhi says: "When

10 In fact, al-'Astarābādī appears to be the only grammarian to recognize clearly this pragmatic dimension of tahș ș and some of the terms derived from it, and that in some well defined contexts. The scope of the present article does not allow me to deal with this topic, which would justify a study on al-'Astarābādī. On the pragmatic aspects of al-'Astarābādī's approach, cf. Larcher (1990, 1992, 1994, 1998 and more generally, 2014). 
you say 'I have twenty', you have made the species imprecise, and when you say 'dirham', you have characterized a species and thanks to this, it is known of what species is this number" ('id ā qulta 'ti 'išrūna' fa-qad 'abhamta l-anwāa fa-'idā qulta 'dirhaman' fa-qad ihtașașta naw'an wa-bihi yu'rafu min 'ayy naw' dâalika l-'adad, Kitāb II, 174, and 192 for a similar example). Although in fact Sïbawayhi's use of the term is not technical, but general (like the other occurrences of ihtișās in the Kitāb), and even if this use does not strictly fall within the framework defined by tahșiş (annexation, qualification, and explanatory apposition), it may very well be the first occurrence of the root $h$-s-s with the technical meaning we are looking for, or perhaps, a proto-manifestation of it.

In contrast, according to Kinberg's index (1996), no trace of tahșiş or any other word of this root occurs in al-Farrā's (d. 207/822) Ma'āni l-Qur'ān, nor does it occur in al-Mubarrad (d. 285/898), neither in his Muqtadab, nor in his Kämil. Nevertheless, at least one occurrence of muhtașs, passive participle of Form VIII, in connection with annexation could count as a proto-technical usage, when al-Mubarrad writes (Muqtadab III, 198) about hamsatahum: "Then you annexed it to its plural and it became particularized by it" ( $f a-$ 'aḍaftahu [hamsa] 'ilājamīihi fa-șāra muhtașșan bihi).

We find again a single occurrence of tahșiș in the 'Ușül fi l-naḥw of Ibn alSarrāj (d. 316/928), in connection with the admirative formula ('Ușūl I, 102). However, while his use of tahṣıss certainly refers to a technical grammatical category, Ibn al-Sarrāj has in mind that of mahșuṣs (bi-l-madhh/bi-l-damm). What is more, some of the terms from the root $h-s-s ̧$ in Ibn al-Sarrāj actually describe the inverse of the phenomenon we are interested in (the first term of annexation particularizing the second, see 'Ușūl I, 85, 153), since he uses mahșuṣs in the sense of muhașaș. Indeed, here is what he writes: "This does not include the case of darabanì gulämu hamsata 'ašara rajulan 'the servant of fifteen men hit me', since 'the servant' is particularized, known and not ambiguous" (walā yadhulu fì hādāa 'darabanì ġulāmu hamsata 'ašara rajulan' li-anna l-ġulām mahșusus malūm ġayr mubham, 'Ușül I, 276). We find here mahșūṣ in the sense of muhașșaș in the technical meaning we are looking for, while we find tahșịs in the sense of mahșuss bi-l-madḥ/damm.

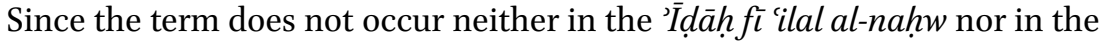
Jumal fi l-nahww of al-Zajjājì (d. 337/949), one might say that al-Zajjājī ignores the notion as such. Indeed, he writes about the active participle:

Know that the active participle, when it has the meaning of the past and you annex it to an indefinite expression, becomes indefinite, and that if you annex it to a definite expression, it becomes definite (wa- 'lam 'anna 
ism al-fāil 'id̄ā kāna bi-ma'nā l-mudiyy fa-'adaftahu 'ilā nakira tanakkara wa-'in 'a daftahu 'ilā ma'rifa ta'arrafa).

Jumal II, 90

Thus, he is aware of the phenomenon of particularization, (in this case with the annexation of an indefinite to an indefinite), but does not link it to the term we know. There is a single occurrence of tahșiṣ in al-Zajjajij’s short treatise Kitāb al-lāmāt, but it lacks the relevant technical meaning (Lāmāt 32).

Presumably, the first occurrence of a derivative of the root $h-s-s$ with an obvious link with the defined technical meaning is in al-Sīräfi's (d. 368/979) Šarh Kitāb Sïbawayhi. It occurs in the chapter on the adjective:

'Abū Sa'ìd [al-Sīrāfì] said that the meaning of the adjective was to characterize the essence of the qualified element and to bring it out from vagueness and general toward a more precise sense. Thus, the adjective brings out the undefined qualified elements of a species toward a more precise kind. As for the [qualified] defined elements, the adjective brings them out from an individual whose name is shared and who is therefore subject to ambiguity at a stage where ambiguity disappears from it. As for the indefinite expression, it is [like] when you say marartu bi-rajulin zarifin 'I passed by a friendly man'. If you limited yourself to 'man', it would have fallen under the set of all men, and the species to which it belongs would have been general, while when you qualify it by 'friendly', it becomes part of the class of friendly men, which is more restricted than men in general ( qāla 'Abū Sa'id ma'nā l-na't 'annahu ihtișāṣ nafs al-man üt wa'ihrāj lahu min 'ibhām wa-'umūm 'ilā mā huwa 'ahaș minhu wa-l-nakirāt al-man'üta yuhrijuhā al-na't min naw' 'ilā naw' 'a haș̣̦ minhu wa-'ammā lma'āriffa-yuhrijuhā l-na't min šahș muštarak al-ism inda wuqū'al-labs fĭhi 'ilà 'an yazūla al-labs 'anhu 'ammā l-nakira fa-qawluka 'marartu bi-rajulin zarîfin' law iqtașarta 'alā 'rajul'wahdahu la-kāna l-rajul waḥdahu min jumlat al-rijāl kullihim wa-naw'uhu llad̄ì huwa minhum al-rijāl 'alā l-'umūmfalammā na'attahu bi-'zarīf' șāra min jumlat al-rijāl al-zirāf wa-huwa 'aqall min al-rijäl bi-ițlāq).

Šarh ${ }_{\text {II, }}{ }_{12} \mathrm{f}$.

Thus, the result of the qualification of an indefinite noun is more precise than the indefinite noun alone, which al-Sīräfĩ expresses in his own way by using ihtișāṣ and 'ahașs. Nevertheless, these are still only proto-technical terms that do not encompass the whole concept defined under tahșiss since they concern only qualification; a fortiori, this is not yet a matter of tahșiș. 
'Abū 'Alī al-Fārisī (d. 377/987) uses tahșiș more frequently than his predecessors. It is found twice in his Kitāb al-'ida āh (208) and twice in al-Takmila (320, 365 ), but in a basic, non-technical meaning. On the other hand, in one particular instance, involving a vocative particle $(\text { nid } \vec{a})^{12}$ functioning as a common factor for two nouns, al-Fārisī writes:

The point of the resemblance of this type with the annexation is that the second [term] particularizes the first, just like the second term of the annexation particularizes the first term of the annexation (wa-wajh šabah

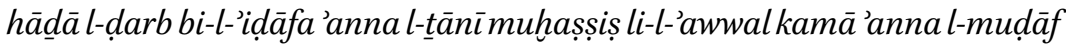
'ilayhi muhașșiș li-l-mudāa f).

'Ị̇āh 190

This passage is quite remarkable, first because as far as I know, this is the first appearance in Arabic grammar of the term muhasșsiș, active participle of tahșiss, used here with its technical meaning in connection with annexation. Further on, again in connection with annexation, but this time with the Form VIII verb ihtașsa, al-Fārisī also refers to the proto-determined character mentioned above:

And when you annex an indefinite [expression] to an indefinite one, it is particularized by the annexation, even if it does not become definite, as in 'a donkey's rider' (wa-'idāa 'adafta nakira 'ilā nakira ihtașsat bi-l-idâafa wa-'in lam tata'arraf naḥwa 'rākibu himārin').

'İ

Apparently, then, al-Fārisī does identify the phenomenon and clearly states that it is connected with tankir and ta'riff. At the same time, it should be stressed that the terminology is still unstable, since he uses a Form viII verb rather than Form II (cf. also Fārisī, Takmila 268). Moreover, he only deals with it as part of the annexation and does not refer to the explanatory apposition, nor to the qualification.

Seven instances of tahșiș are found in Ibn al-Warrāq's (d. 381/991) Ilal al$n a h w$, where it occurs both in connection with annexation (Ilal 145, 228, 304) and with qualification ( Ilal 371, 380). As for the annexation, Ibn al-Warrāq says:

12 This case involves the use of yā țalātatu wa-l-talätüna 'o, thirty-three!' when addressing a group of people: wa-law nādayta jamā'atan hädihi l-'idda 'iddatuhà la-rafa'ta fa-qulta yā talātatu wa-l-țalātūna fì-man qāla zaydu wa-l-ḥārițu wa-man qāla wa-l-hārița nașaba altalātīina 'aw qāla yā talātatata wa-[yā] țalātūna. 
The characteristic feature of annexation is that the first term of annexation is particularized. [...] Don't you see that if you said $h \bar{a} \underline{d} \bar{a} \dot{g} u l \bar{a} m u n$ 'He is a servant', it would be ambiguous, but when you say gulämu zaydin 'Zayd's servant', he is distinguished by the fact that he is Zayd's possession

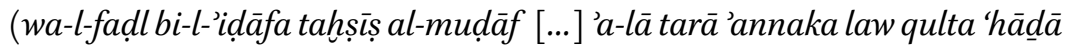
gulāmun' la-kāna mubhaman fa-'idāa qulta 'g்ulāmu zaydin' ihtașșa bi-milk zayd).

Ilal 145

As for the qualification, Ibn al-Warrāq writes: "Regarding the indefinite expression [...], the adjective only signifies in it a particularization" ('amma l-nakira [...] fa-l-șifa 'innamā tufidu fìha tahșisșan, 'Tlal 371) and "as for the indefinite expression, the principle in it is to be qualified because the aim of the qualification is the particularization of the qualified element" (wa-'amma l-nakira fa-l-'așl fiha à an tun'ata li-'anna l-ġarad min al-na't tahșișal-man'üt, 'Ilal 380). As we see, tahșiş appears in connection with qualification and annexation and in the framework of indefiniteness since the first term of annexation and the qualified element are both indefinite. Thus, it could correspond to the ideal-typical definition given above, but for Ibn al-Warrāq annexation has the property of defining the first term since he writes that "the first term of annexation takes on definiteness from the second term" (wa-l-mudāf yaktasibu ta'rïfan min almudāf 'ilayhi, Tlal 383) and that "the first term of annexation is supposed to be an indefinite expression before annexation and then to be annexed, because the aim of annexation is its definition" (al-mudāf yuqaddaru qabla l-idāfa

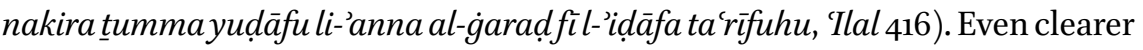
is the following statement:

The characteristic of annexation is the particularization of the first term and its definition. When the first term has the article, it becomes defined by it and does not need another definition by means of annexation (al-fașl

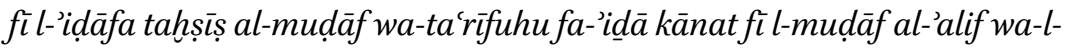
lām ta'arrafa bihimā wa-lam yahtaj 'ilā ta'rīf 'āhar min jihat al-'ị̂āa).

Ilal 304

Thus, for Ibn al-Warrāq, annexation always involves definiteness and particularization, while qualification only involves particularization within the framework of indefiniteness. In particular, Ibn al-Warrāq does not address the case where the second term of annexion is itself indefinite (as in bayt mu'allim), which shows that, unlike later grammarians, he does not take into account this phenomenon. 
At least one passage of the Šarḥ Kitāb Sïbawayhi of 'Abū l-Hasan al-Rummānì (d. 384/994) suggests that he is aware of this phenomenon: "... since the governed element particularizes, as does annexation and as does the adjective"

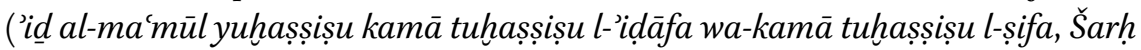
I, 374). Here indeed we find for the first time the Form II verb hașșașa, both in connection with annexation and with qualification.

Apart from the many occurrences of the expression tahșiș al-illa in the Hașāis of Ibn Jinnī (d. 392/1002), tahșiș often has the technical meaning we are dealing with. He writes: "In fact, the adjective in the utterance is of two types: either it serves specification and particularization, or praise and eulogy"

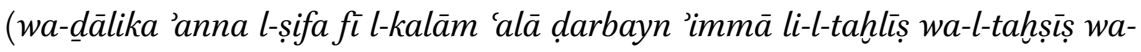
'immā li-l-madḥ wa-l-tanā', Hașā̉iṣ II, 146). In another passage, which has no connection with qualification, but only with annexation, Ibn Jinnī writes: "It has been said that the purpose in annexation is only to define and to particu-

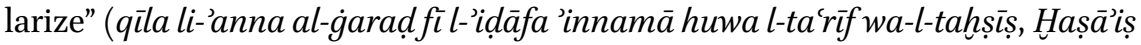
II, 267). This is expressed in the same way in his Sirr șinácat al-i'irāb where he states that "annexation imparts definiteness and particularization" (al-id̄a $f a$ tuksibu l-ta'rîf wa-l-tahș̣̄ṣ, Sirr II, 37). With Ibn Jinnī we thus clearly pass from Form VII i intaṣṣa to Form II hașṣaṣa, and more specifically, to its mașdar. This means that with Ibn Jinnī the notion of tahșiș, for the first time in the history of Arabic grammar, acquires the familiar technical meaning. This transition to Form II is understandable, because it fits into a set of systematic notions from this form, such as tankir and ta'rîf. Moreover, it allows the formation of pairs of terms, of which Arabic grammar is fond, such as mudāf and mudāa 'ilayhi, man'ūt and na't, mawșūf and șifa, mubdal and mubdal minhu, mustatnā and mustatnā minhu, etc. From the factitive Form II, pairs of terms distinguishing an agent from a patient may be derived, such as munakkir and munakkar, mu'arrif and mu'arraf, muhașșiṣ and muhașșaṣ. Nevertheless, Ibn Jinnī appears to be less explicit than al-Fārisī about the connection of tahșịs with tankïr and ta'riff.

Nothing is found concerning our subject in Ibn Fāris' (d. 395/1004) Maqāyīs,

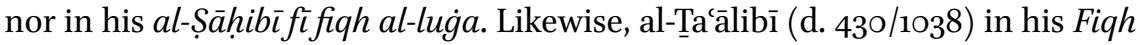
al-lugia wa-'asrār al-'arabiyya has only one instance of tahșiṣ in a basic sense (Fiqh al-luga 391), while the technical meaning is absent from his work.

Ibn Sīda (d. 458/1066) recognizes the phenomenon of tahșịs in his Muhașșaș in the context of qualification as he writes: "Its particularization by means of annexation became like its particularization by means of qualification" ( $f a$ șāra tahșișuhu bi-l-ị̂āfa ka-tahșișsihi bi-l-wașf, Muhașșaṣ XVI, 66), providing as an example sayrun šadidun 'a difficult walk', i.e., the qualification of an indefinite noun by an indefinite adjective. 
'Abd al-Qāhir al-Jurjānī (d. 471/1078), a student of a nephew of al-Fārisīi,13 illustrates a new turning point in the terminological history of tahșiss by placing it in a precise system and by explicitly linking it to the framework of indefiniteness:

Know then that, with respect to indefinite expressions, the adjective conveys particularization and, with respect to definite expressions, clarification. The explanation for this is that when you say marartu bi-rajulin tawilin 'I passed by a tall man', you reduce the generality of the noun by making it apply to only part of [its] species, rather than to its entirety, insofar as you do not include in it any man who is not tall. This is the meaning covered by particularization and it only occurs with the indefinite expression (țumma ilam 'anna l-șifa tufidu fíl-nakira al-tahșiș wa-fì l-

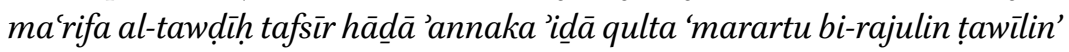
kunta qad naqașta min 'umūm al-ism fa-ja'altahu yaqa'u 'alä ba'd al-jins dūna kullihi min hayțu là tudhilu man lā yakūnu țawìlan min al-rijāl fìhi fa-hāḍā huwa l-murād bi-l-tahșịș wa-lā yakūnu 'illā fì l-nakira).

Šarḥ 276; see also Muqtaṣid II, 175

Thus, al-Jurjānī is the first to be as clear on the distinction between tahṣiș and tawdih , which is therefore understood to be its complementary rather than its equivalent. ${ }^{14}$ Yet, tahșiș is limited here to qualification, while nothing is said about tahșiș in annexation.

Finally, 'Abū l-Qāsim al-Zamahš̌arī (d. 538/1144) provides the first accurate description in the history of Arabic grammar of tahșiss, as we currently understand it: 15

Annexation of a noun to a noun is of two types: semantic and formal. The semantic one signifies definiteness, as when you say dāru 'amrin "Amr's house', or ('aw) particularization, as when you say gulāmu rajulin 'a man's servant' ('ịäfat al-ism li-l-ism 'alā darbayn ma'nawiyya wa-lafziyya fa-l-

\footnotetext{
13 He was the student of 'Abū l-Ḥusayn Muhammad ibn al-Ḥasan ibn Muhammad ibn alḤusayn ibn 'Abd al-Wāriț al-Fārisī al-Naḥwī (d. 421/103o), himself a nephew by his mother of 'Abū 'Alī al-Fārisī (cf. Jurjānī, Šarh 3o). On al-Jurjānī see Larcher (1993).

14 This case is dealt with in a forthcoming study, "Definition and determination in Medieval Arabic grammatical thought", to appear in the proceedings of the 4th Conference on the Foundations of Arabic Linguistics.

15 Troupeau (1993:1034a) effectively notes the presence of this term in al-Zamahšarī.
} 
ma'nawiyya mā 'afāda ta'rîfan ka-qawlika 'dāru 'amrin' 'aw tahșịșan kaqawli-ka 'g̀ulāmu rajulin').

Mufașșal 119

As we see, al-Zamahšarī carefully distinguishes between ta'rīf and tahṣiş̣. He does so by using two contrastive examples: a definite second term of annexation for ta'rîf, and an indefinite one for tahșiss. He also does so by using an actually disjunctive coordination, 'aw, where others before him had used wa-, so that the disjunction had to be imagined. In another passage, this time in connection with the treatment of the adjective, he writes: "It is said that it serves for particularization within the indefinite expressions and for clarification within the definite ones" (wa-yuqālu 'innahä li-l-tahșịs fì l-nakirāt wa-li-l-tawdịh fị lma'ārif, Mufașsal 148).

While the work of al-Suhaylī (d. 581/1185) provides us with only a few instances of this term (Natâ $i j 28$ for annexation, and 158 for qualification), it is clear that tahșișs, in and after al-Zamahšarī, is the act of particularizing an indefinite noun by the second term of an annexation, itself indefinite, or by a following indefinite adjective. In either case, tahșiş is linked to the state of tankìr. It is something else than $t^{\prime}{ }^{\prime} r i f$ and has a complementary term within the state of ta'iff, that of tawdih. We find the same technical uses and the same systematic relations in later grammarians. ${ }^{16}$ Within the line of the Mufașsal, this is the case of Ibn Yacǐš (d. 643/1245) (cf. Šarh II, 126, 233), Ibn al-Ḥājib (d. 646/1249) (cf. Käfiya 122, 129, 'Imlā' 43a-b, 45b, 48a) and Raḍī al-Dīn al-'Astarābādīi, in whose approach this category takes a more pronounced pragmatic dimension, tahșiș and its derivatives being connected to the notions of speaker (mutakallim) and interlocutor (muhāțab) (cf. notably Šarh al-Käfiya I, 202 ff., in particular 206;17 II, 238 f.; II, 314).

Although al-Zajjājī does not mention tahșiş at all or even ignores the phenomenon, Ibn Harūf (d. 6og/1212), commentator of al-Zajjajjìs Jumal, should be partly included within al-Zamahšarīs legacy, since for him "the adjective serves to particularize the indefinite expression and to remove the supposed equivocity concerning the definite qualified element" (wa-fäidat al-na't tahșịs al-nakira wa-raf' al-ištirāk al-mutawahham fì l-man'üt al-ma'rifa, Šarh I, 300).

16 In the appendix two grammarians will be dealt with, whose use of tahșịs is sufficiently against the current to warrant separate treatment, Ibn al-'Anbārī (d. 577/1181) and 'Abū Mūsā al-Juzūlī (d. 6o7/1210 or 616/1219).

17 I refer here to Larcher (1983:253) about saläm which "is specified by its relation to the one that greets", muhtașs bi-. 
Nevertheless, he presents an example such as șāhibu zaydin as a case of tahșịș, which it is not, and thus shows that the terminology, while certainly being more stable, is not identical for all grammarians. Ibn 'Ușfūr (d. 669/1271) has the same terminology as al-Zamahšanì in the matter (cf. Šarh I, 141-143, 164; II, 171). By contrast, Ibn al-Fahhhār (d. 754/1353) returns to the use of ihtișās for the qualification of an indefinite expression (Šarh I, 131), but he does keep tahșisș in the case of annexation (Šarh I, 495).

Ibn Mālik (d. 672/1274) recognizes the phenomenon, both in his 'Alfiyya and his Käfyya al-šäfrya. About the semantic (or pure) annexation he says:

All of that is what its annexation is semantic, real and pure as it affects the first term of annexation, defining it if the second [term] is a definite expression, and particularizing it if the second is an indefinite expression ( fa-hädihi kulluhu mimmā iḍäfatuhu mánawiyya wa-haqìqiyya wa-

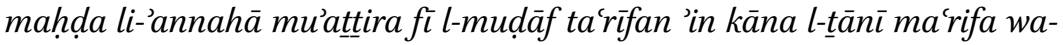
tahșịsan in kāna l-țānī nakira).

Šarh I, 408

He does the same for qualification by an adjective. Yet, his examples concern qualification of nouns already definite, so that they do not fall within the strict framework of the ideal-typical definition of tahșiș (cf. Šarh I, 520). Ibn Hišām al-'Anșāin (d. 761/136o) also uses the term with its technical meaning ('Awḍh III, 71, 256; Sabül al-hudā 347 [twice, hăal], 377 [twice], 378 ['iduăfa], 416 [twice, na't] ] 434f. ['atf]) as well as derived terms (Ibn Hišām al-'Anșārī Sabīl alhudā: muhașșașa 347 [hāl]; muhașșiș 433 [twice], 434 ['atf]). Finally Ibn 'Aqīl (d. 769/1367) uses tahṣı̄ṣ in the same way (Šarh I, 368f.).

Let us go back to Ibn Mālik in order to draw conclusions about the development of the conceptual content of tahșịș. First, Ibn Mālik, just like Ibn 'Aqīl later

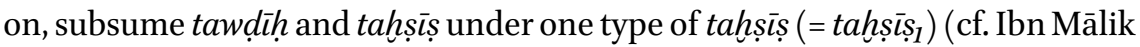
Šarh I, 520 and Ibn 'Aqīl Šarḥ II, 43). This is not what Ibn Hišām does, because he always distinguishes between definite and indefinite nouns ('Awdah III, 64, 223, 256; Sabīl al-hudā 416, 433-435). But Ibn Mālik is also the one who expands the category of tahșiss beyond the borders of qualification and annexation, and he is followed in this by his commentators. He begins by extending it to the explanatory apposition ('atfal-bayān), close to the adjective (cf. Ibn Mālik Šarh I, 533). Following him, Ibn Hišām al-'Anșārī does the same; he writes in connection with the explanatory apposition with tahṣṣss:

The explanatory apposition is the appositive that looks like an adjective, clarifying its subordinate if it is a definite expression and particularizing 
it if it is an indefinite one ('atf bayān wa-huwa l-tābi' al-mušbih li-l-șifa fì taw dịh matbū'ihi 'in kāna ma'rifa wa-tahșiș̣ihi nakira).

'Awḍậ III, 256; see also Sabül al-hudā 434f.

Furthermore, he observes about muhașșiș:

I have referred with the two examples to what is included in the definition in terms of its being used to clarify the definite [expressions] and particularize the indefinite ones ('ašartu bi-l-mitāalayn 'ilā mā tadammanahu l-hadd min wuqū ihi muwaḍiḥan li-l-ma ārif wa-muhașșișan li-l-nakirāt). Sabïl al-hudā 434

Finally, Ibn Mālik (Šarh I, 331) incidentally couples tahṣiṣ with tamyizz, when he quotes the Qurānic verse 41/10 fì 'arba'ati 'ayyāmin sawāan li-l-sầilīna 'in just four days. [This refers to] those who question' (Blachère 1950:506), to illustrate the fact that tahșiss serves within an annexation in the framework of indefiniteness, here with 'arba'at 'ayyām. The numerals in the segment [310], as well as for full hundreds and thousands, are therefore subject to tahșiș (annexation of an indefinite second term), while the complementary term in the segment [11-99] is the tamyīz..$^{18}$ Ibn Hišām al-'Anșārī (Sabīl al-hudā 347) and Ibn 'Aqil (Šarh I, 321) proceed in the same way with this example.

Tahșiș as a technical term is connected with tankir and ta'rîf; its complementary terms are in intension, tawdīh (or others on which I will focus elsewhere) and in extension, tamyiz. Technically, tahșiss means the particularization of an indefinite noun by another indefinite element (the second term of an annexation or a qualification in the broad sense that includes the attributive qualification, the explanatory apposition, and the prepositional group). It is therefore surprising that this technical term, with its long history, thus far has not attracted more interest, and even more that this term is far from unknown or ignored in other fields than grammar.

18 This is echoed at a late period by al-Kafawī (d.1094/1683) al-tahṣiș wa-huwa l-ḥukm bi-țubūt al-muhașșaș li-šay'wa-nafyihi 'ammā siwāhu [wa-kilāhumā 'ibarātān 'an ma'nā wāḥid] wayuqālu 'ayḍan tamyizz 'afrād ba'd al-jumla bi-ḥukm ihtașșa bihi (Kulliyyāt 284, 422), and more recently by Baraké (1985:154). 
Relatively unknown or ignored in grammar, tahșiş is rather well represented as a category or technical term in the field of 'ușull al-figh, translated by Larcher (1988:122, Larcher 1991:185) as 'jurologie'. Sānū (2000:126) reserves for this term an entry in his Mújam mușțalahăt 'ușūl al-figh, and translates tahșịs in English by 'specification'.19 Similarly, Hilāl (2003:71-78) devotes eight pages to the study of tahșiş in jurology. He distinguishes tahașșus from tahșiṣ and subdivides the latter in several subentries. Finally, entire books are reserved to it. 'Umar ibn 'Abd al-'Azīz al-Šaylahānīi is the author of a book on the issue of tahșiș among legal scholars, entitled Mabāḥiț al-tahșịs 'inda l-'ușūliyyinna (al-Šaylahānī 200o), and 'Ismācill Muhammad 'Alī 'Abd al-Raḥmān devotes to it a monograph enti-

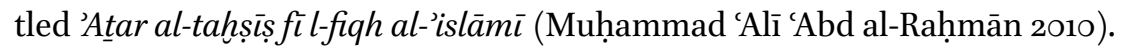

In the Classical Arabic period, the list of specialists in 'ușül al-figh who deal with tahșiș would become too long. As a matter of fact, this category is dealt with extensively in one or more sections of its own, unlike its status in grammar. $^{20}$ Finally, tahșiss is not only well-known among Arab specialists in legal theory, but also among Arabist specializing in this field, ${ }^{21}$ although, just like in studies on Arabic grammar, it has not been the subject of special studies.

As for al-Šaylahānī (2000:128, 212), he focuses on legal scholars, but does not forget to mention Ibn al-Ḥājib. The latter, in addition to being known in the Orientalist West as a grammarian, is indeed also known in the East as a legal

19 al-tahșiș̣: min hașșașahu bi-l-šay' 'id̄a qașarahu 'alayhi. qașr al-āmm 'alä ba'ḍ 'afrādihi bi-dalīl, muțlaqa qașrin sawā' 'a-kāna dālika al-dalīl mustaqillan, 'am ġayr mustaqill, wasawā' 'a-kāna muqtarinan bi-l-dalīl al-'āmm al-murād tahș̦ișuhu, 'am kāna ġayr muqtarin bi-hi. mițāluhu qawluhu [...]: "wa-'ahalla llāhu l-bay'a wa-harrama l-ribā" [Q. 2/275], fakalimat al-bay'tašmulu al-ribā li-'anna al-bay'mubādalat māl bi-māl, wa-ka-d̄àlika al-ribā fa-innahu mubādalat māl bi-māl ma'a al-ziyāda, wa-li-d̄àlika haș̣așa qawlahu [...]: "waharrama al-ribā" al-'umūm allad̄ì warada fì qawlihi: "wa-'ahalla llāhu l-bay'a" [...]

Among legal scholars dedicating a whole section to tahșịs are: Rāzī, Mahșūl III, 7 f.; 'Āmidī, 'Inkām II, 485f.; 'Ījī, Šarh 208f.; Ibn al-Najjār, Šarh III, 267 f.; 'Anșārī, Fawātịh I, 30of.; Zarkašī, Tašnîf II, $715 \mathrm{f}$.

21 One finds it mentioned in several authors, and notably so in the Encylopaedia of Islam: Layish (1991:41a); Paret (1997:256a-b, 258b); Chaumont (2009: §9). See also Weiss (1984), who elsewhere (2000:867a) specifies: "Many pages in the ușülal-fikh literature are devoted to the subject of 'particularisation of the general expression' (takhșiș al-'ämm). An interpreter was always obliged to look for a 'particulariser' (mukhașșiş, dalïl al-takhsșiss) in the context before making a final conclusion concerning the scope of reference of a general expression". 
scholar. ${ }^{22}$ As a legal scholar and a grammarian, he informs us about the status and origin of tahșiss. Apparently, since he dedicates an entire section of his Muhtașar Muntahā to tahșiș, ${ }^{23}$ something he does not do in his grammatical works (neither in the Käfyya, nor in the 'Imlä' 'alä l-Käfrya, nor in the 'İ šarh al-Mufașsal), for him tahșiș is first and foremost a legal category (as proven by the entries in 'ușül al-figh) rather than a grammatical one (as proven by the absence of systematic treatment of this category in grammar).

Here, I will confine myself to speculate that al-Fārisī, or his student Ibn Jinnī (or even al-Rummānī), the former being the first in the history of Arabic grammar to use the term muhașsiș, the latter being the one who innovated by introducing the mașdar related to this active participle, i.e. tahșișs, may have been the ones responsible for the introduction of this concept from the 'ușūl al-fiqh.

What is certain is that al-Šăfici (d. 204/819) almost never employs the root $h-s-$ $s^{24}{ }^{24}$ while al-Bāqillānī (d. 403/1012) quotes tahșiș (cf. Bāqillānī, Taqrīb III, 63) ${ }^{25}$ The answer to the question which one of them (or one of his successors) could have invented the concept and introduced it into grammar must be looked for between these two extremes and in particular in the works on țabaqät al'ușüliyyina. After having consulted one of these books, the Fath al-mubin fi țabaqāt al-'ușüliyyinna of al-Murāgì, and assuming that the person I was looking for was a contemporary of al-Fārisī, I found no fewer than 26 legal scholars, from Ibn Sarīj al-Šāfiì (d. 306/9o8) to 'Abū l-Qāsim al-Ṣaymarī al-Šāfīi (d. 386/996) (cf. Murāgīi 1947:I, 204-249). I leave this work of archeology on tahșịṣ in the 'ușūl al-figh to specialists in Islamic law.

He is notably the author of Muntahäl-su'alwa-l-'amalfí 'ilmay al-'ușūlwa-l-jadal, a treatise on the sources of law according to the Maliki school, and a treatise in which he summarizes the 'Ihkām of Sayf al-Dīn al-'Āmidī (d. 631/1233). From the first he brings out a summary, the Muhtașar Muntahā l-su'al wa-l-amal fì 'ilmay al-'uṣül wa-l-jadal.

23 Cf. Ibn al-Ḥājib, Muhtașar 786-858.

24 Only three times yahuș̣su is found in the Risāla, but neither ihtișāṣ nor tahṣșṣ nor any verbal or nominal derivative.

25 The first definition of tahșiș in 'ușūl al-figh appeared later in the work of 'Abū al-Ḥusayn al-Bașrī (d. 436/1044). At least, this is what 'Ismā'ill Muḥammad 'Alī 'Abd al-Raḥmān, professor of 'ușūl al-figh at the faculty of King Sa'ūd in Riyadh says. According to him (2010:4), al-Bașrī defined tahșiș as "extracting a part of what the speech deals with being linked to it" ('ihrāj ba'ḍ mā tanāwalahu l-hițāb ma'a kawnihi muqārinan lahu). This definition presumably derives from another edition of the Mu'tamad (Beirut: Dār al-Kutub al-'Ilmiyya, 1982) than mine, where it is absent, although it may actually be recontructed like this (cf. Bașrī, Mu'tamad I, in particular 201f., 231). 
The category of tahșiș in Arabic grammar relates, first, to annexation, then to qualification, and later to explanatory apposition. It forms a terminological pair with tamyiz. It is connected with tankir and ta'riff, and is to be understood as 'particularization'26 (that is to say a kind of 'determination'). It is complementary to other terms, including taw dị h 'clarification'. In this context, it refers to the particularization of an indefinite noun by another indefinite element, which can also be a prepositional group, the noun of the group being definite or not.

Probably, al-Sīrāfî (d. 368/979) was the first to refer to a closely related meaning, although without using the term itself (since he uses ihtișāss), but 'Abū 'Alì al-Fārisī (d. 377/987) should be considered the one who introduced this category in grammar. He did so through the active participle of Form II muhașșiș, and was followed in this by al-Rummānī, who used the finite verb of Form II (tuhașşișu and yuhașşișu). Ibn al-Warrāq (d. 381/991) uses tahșiş in a sense quite close to the later definition, but he does not explicitly distinguish between it and ta'îf (with respect to annexation) and consequently, he does not present it as something connected with tankir and ta'rîf, as will be the case afterwards. Ibn Jinnī (d. 392/1002), himself a student of al-Fārisī, develops this heritage, notably through the verbal noun tahșiș. This legacy is reinforced later by Ibn Sīda (d. 458/1066), but especially by 'Abd al-Qāhir al-Jurjānī (d. 471/1078), a student of a nephew of al-Fārisī, and even more so by al-Zamahšarī (d. 538/1144), who gives a systematic presentation of tahșiș, but only within the state of tankir or below the state of ta'rif.

With respect to the origin of the term, Fleisch points out critically:

Sïbawayhi, raised on the shield by al-Mubarrad, obtained immense authority: he became the master par excellence. In principle, everything had to be found in the Kitāb, which came to be called: Qur'ān an-nahw 'grammar's Quran'. His views, his opinions were to be the only accurate ones. One came to draw conclusions, not only on the basis of his words,

26 It should be distinguished from 'specificity', as used by Lyons (1999:165-178), tahṣı̄ṣ being a kind of determination specially not linked with referentiability. Moreover, tahșisṣ is not the only term meaning a kind of determination, as I will show in my forthcoming publication in the proceedings of the 4 th Conference on the Foundations of Arabic Linguistics, where the term will be dealt in connection with 'specification, 'clarification', 'elucidation', and even 'completion', all of those terms being kinds of special determination. This also explains why tahșiṣ is translated here by 'particularization'. 
but also his silences (just as was done with the Prophet of the Arabs): consequently, what was not found in the Kitāb, was dismissed beforehand, as devoid of authority. ${ }^{27}$

It is clear that as a technical term, tahșiș - certainly not the most important term in Arabic grammar, although we have seen that its full scope encompasses both annexation and qualification, as connected with between ta'irif and tankir - is not present in Sïbawayhi, nor in his immediate successors. However, the term did have a place in the Arabic grammatical tradition and it has maintained this place till the present day, as we find it in a few well-informed modern authors. We must therefore conclude, in accordance with Fleisch's criticism, that not everything is said in Sībawayhi's Kitāb.

\section{Appendix: Two Dissenting Grammarians}

In his book 'Asrāral-'arabiyya Ibn al-'Anbārī (d. 577/1181) uses tahṣiș̣ in a quite surprising way, compared to the other grammarians. First, with respect to annexation, he writes that "impure annexation does not signify ta'rîf, ${ }^{28}$ unlike the pure one, as in gulämu

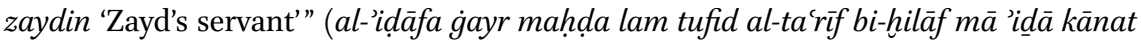
mahda nahw 'gulämu zaydin', 'Asrār 151). Apparently, he does not distinguish within the pure annexation between those cases where the second term is definite and those where it is not. Even more surprising terminologically, is Ibn al-'Anbārî's usage in connection with qualification:

If someone asks 'what is the purpose of qualification?', he is told that it is particularization and distinction. Thus, if it is a definite expression, the purpose of qualification is particularization, because of the inherent equivocity. Don't you see that there are many people called Zayd or something similar, so that when we say jäanai zaydun 'Zayd came to me', it is not known which one of

27 "Sībawayhi, élevé sur le pavois par al-Mubarrad, obtint une autorité immense: il devint le Maître sans plus. En principe, tout devait se trouver dans le Kitāb, que l' on vint à appeler: Qur'ān an-naḥw 'le Coran de la grammaire'; sa manière de voir, ses opinions devaient être les seules exactes. On en vint aussi à conclure non seulement de ses dires, mais de ses silences (comme pour le Prophète des Arabes): ainsi, ce que l'on ne trouvait pas dans le Kitāb était d' avance écarté comme dénué d' autorité" (Fleisch 1961:I, 34).

28 I have chosen not to translate ta'rîf here, because it clearly does not refer to definiteness, but rather to what the other grammarians call tahsṣiș, i.e. 'determination', which cannot serve to translate ta'rïf as such. 
them we mean? Thus, when we say zaydun al-ãqilu 'Zayd the intelligent' or al'älimu 'the learned' or al-'adību 'the educated', or something similar, we single him out from among the others. Now, if the noun is an indefinite expression, the purpose of qualification is distinction. Don't you see that when you say jāani rajulun 'a man came to me', it is not known which man is meant, and that when you say rajulun 'àqilun 'an intelligent man', you distinguish him from those who do not possess this qualification, and that it is not a matter of particularizing him, because by distinguishing we mean a specific entity, which was not aimed

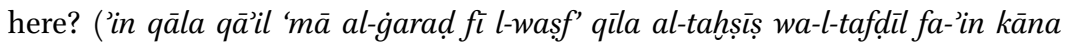
ma'rifa kāna l-garad min al-waşf al-tahșiș̣ li-'anna l-ištirāk yaqa'u fìhā 'a-lā tarā 'anna l-musammà bi-'zayd'wa-naḥwihi kațīr fa-'idāa qāla 'jā'ānìzaydun' lamyu'lam 'ayyahum yurìdu fa-'idā qāla 'zaydun al- 'āqilu' 'aw 'al- 'ālimu' 'aw 'al-'adību'wa-mā 'ašbaha d̄ālika fa-qad haș̣̦ahu min ġayri-hi wa-'in kāna l-ism nakira kāna l-ġarạ min al-wașf al-taf̣̂̄l 'a-lā tarā 'annaka 'id̄ā qulta 'jāanī rajulun' lam yu'lam 'ayy rajul huwa fa-'idā qulta 'rajulun 'āqilun' fa-qad faḍdaltahu 'alā man laysa lahu

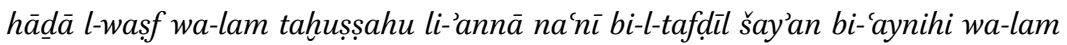
nuridhu hāhunā).

'Asrār 155

What is particularly interesting here is that, while distinguishing within the qualification of a noun between its definiteness or indefiniteness, and while reserving two different technical terms for each of these qualifications, Ibn al-'Anbārī does not comply with the terminology. Indeed, for him, $\left.\operatorname{tahșiș~(=~} \operatorname{tahșis_{2}}{ }_{2}\right)$ corresponds in fact with the complementary term to tahșis of the other grammarians, while tafdill, a term encountered anywhere else with that sense, is, on its own, the equivalent of tahșiș among other grammarians.

The second a-typical grammarian is 'Abū Mūsā al-Juzūlī (d. 6o7/1210 or 616/1219) who, perhaps because he was Andalusian, used a different terminoly or, at least in this case, one that was less stabilized. First of all, for him tahșiș (= tahșișs ${ }_{3}$ ) clearly is the union of ta'riff and tahșis according to the sense given by the other grammarians (cf. Muqaddima 8f., 57, 84). Nevertheless, this does not prevent him, while addressing annexation, from distinguishing between 'ị̂a fa maḥ̣ and 'ị̂ăfa gayr maḥ̣a, and from specifying then that "pure [annexation] is what signifies definiteness or particularization" (al-maḥ̣a mā 'afāda tárīfan 'aw tahșișsan, Muqaddima 131). Doing so, he returns to the use of 'Oriental' terminology. At last, he renders at least once tahșiș with its technical sense by ihtișāṣ (cf. Muqaddima 94). As a consequence of this, ihtișāṣ, which one can find in the works of other grammarians with the general meaning of particularization, particularly correlated with the particle $l i$-, is then rendered by 'Abū Mūsā by tahṣiṣ (cf. Muqaddima 128). 


\section{Bibliographical References}

\section{A Primary Sources}

'Āmidī, 'Iḥkām = 'Alī ibn Muhammad al-'Āmidī, al-'Ihkām fì 'uṣūl al-'ahkām. Ed. by 'Abd al-Razzāq 'Afîfî. 4 vols. Riyadh: Dār al-Ṣamīīì, 2003.

'Anșāīī, Fawātiḥ = 'Abd 'Alī Muḥammad ibn Nizāām al-Dīn Muḥammad al-Sahālawī al'Anșārī, Fawātiḥ al-rahâ̄mūt bi-Šarh Musallim al-Ṭubūt. Ed. by 'Abdallāh Maḥmūd Muḥammad 'Umar. 2 vols. Beirut: Dār al-Kutub al-'Ilmiyya, 2002.

'Astarābād̄ī, Šarḥ al-Kāfiya = Raḍi l-Dīn Muḥammad ibn al-Ḥasan al-'Astarābād̄ī, Šarh Kāfiyat Ibn al-Hājïb. Ed. by 'Imīl Badī'Ya'qūb. 5 vols. Beirut: Dār al-Kutub al-'Ilmiyya, 1998.

Bāqillānī, Taqrīb = 'Abū Bakr Muḥammad ibn al-Ṭayyib al-Bāqillānī, al-Taqrīb wa-l'iršād. Ed. by 'Abd al-Hamīd ibn 'Alī 'Abū Zaynab. 3 vols. Beirut: Mu'assasat alRisāla.

Bașrī, Mu'tamad = 'Abū l-Ḥusayn Muhammad ibn 'Alī ibn al-Ṭayyib al-Bașrī al-Mu'tazilī, Kitāb al-mu'tamad fì 'uṣūl al-fiqh. Ed. by Muḥammad Ḥamīd Allāh et al. 2 vols. Damascus: s. p., 1964.

Fārisī, Takmila = 'Abū 'Alī al-Ḥasan ibn 'Aḥmad ibn 'Abd al-Ġaffār al-Fasawī al-Fārisī al-Naḥwī, al-Takmila. Ed. by Kāẓim Baḥr al-Murjān. 2nd ed. Beirut: 'Ālam al-Kutub, 2010.

Fārisī, 'Ị̇̂ah = 'Abū 'Alī al-Ḥasan ibn 'Aḥmad ibn 'Abd al-Ġaffār al-Fasawī al-Fārisī alNaḥwī, Kitāb al-'ị̣̂ăh. Ed. by Kāẓim Baḥr al-Murjān. Beirut: 'Ālam al-kutub, 2011.

Ibn al-'Anbārī, 'Asrār = 'Abū l-Barakāt 'Abd al-Raḥmān ibn Muḥammad ibn 'Ubaydallāh al-'Anșārī al-'Anbārī, 'Asrār al-'arabiyya. Ed. by Ḥusayn Šams al-Dīn. Beirut: Dār alKutub al-'Ilmiyya, 1997.

Ibn 'Aqīl, Šarh = Bahā' al-Dīn 'Abdallāh ibn 'Abd al-Raḥmān ibn 'Abdallāh al-Qurašī alHāšimī al-'Aqīlī al-Hamdānī al-Mișrī Ibn 'Aqīl, Šarḥ Ibn 'Aqül 'alā 'Alfiyyat Ibn Mālik. Ed. by 'Imīl Badī' Ya'qūb. 7th ed. 2 vols. Beirut: Dār al-Kutub al-'Ilmiyya, 2010.

Ibn al-Faḩhār, Šarh = 'Abū 'Abdallāh Muhammad ibn 'Alī ibn 'Aḥmad Ibn al-Fahhhār, Šarh al-Jumal. 2 vols. Ed. by Raw`‘ Muḥammad Nājī. Beirut: Dār al-Kutub al-'Tlmiyya, 2013.

Ibn Fāris, Maqāȳ̄s = 'Abū l-Ḥusayn 'Aḥmad ibn Zakariyā' al-Qazwīnī al-Rāzī Ibn Fāris, Mujam maqāyīs al-luġa. Ed. by 'Abd al-Salām Muhammad Hārūn. 6 vols. Repr., Beirut: Dār al-Fikr, 1991.

Ibn Fāris, Șạhibì = 'Abū l-Ḥusayn 'Aḥmad ibn Zakariyā' al-Qazwīnī al-Rāzì Ibn Fāris, alȘāhibū fı fiqh al-luġa al-'arabiyya wa-masā̉ilihā wa-sunan al-'Arab fı̀ kalāmihim. Ed. by 'Aḥmad Ḥasan Basj. Beirut: Dār al-Kutub al-'Tlmiyya, 1997.

Ibn al-Ḥājib, Kāfiya = 'Abū 'Amr Jamāl al-Dīn 'Uțmān ibn 'Umar ibn 'Abī Bakr ibn Yūnus Ibn al-Ḥājib al-Miṣrī al-Dimašqī al-Mālikī, al-Kāfiya fı̀ l-naḥw. Ed. by Ṭāriq Najm 'Abdallāh. Jeddah: Maktabat Dār al-Wafā', 1986. 
Ibn al-Ḥajib, Muhtaṣar = 'Abū 'Amr Jamāl al-Dīn 'Uțmān ibn 'Umar ibn 'Abī Bakr ibn Yūnus Ibn al-Ḥājib al-Miṣrī al-Dimašqī al-Mālikī, Muhtașar Muntahā al-su’al wa-l'amalfí 'ilmay al-'uṣūlwa-l-jadal. 2 vols. Ed. by Nad̄ìr Hamādū. Beirut: Dār Ibn Ḥazm, 2006.

Ibn al-Ḥājib, 'Imlā' = 'Abū 'Amr Jamāl al-Dīn 'Uțmān ibn 'Umar ibn 'Abī Bakr ibn Yūnus Ibn al-Hājib al-Mișrī al-Dimašqī al-Mālikī, al-'Imlā' 'alā l-Kāfiya fi l-naḥw. Ed. by Sartori (2012).

Ibn Hูarūf, Šarh = 'Abū l-Ḥasan 'Alī ibn Muhammad ibn 'Alī Ibn Hูarūf al-'Išbīlī, Šarh Jumal al-Zajjāji. Ed. by Salwā Muḥammad 'Umar 'Arab. Mecca: Jāmi'at 'Umm alQurā, 1998.

Ibn Hišām, Sabūl al-hudā = Jamāl al-Dīn 'Abū Muḥammad 'Abdallāh ibn Yūsuf ibn 'Aḥmad Ibn Hišām al-'Anșārī, Sabūl al-hudā 'alā šarḥ Qaṭr al-nadā wa-ball al-șadā wa-ma'ahu Risāla fı madḥ al-naḥw. Ed. by Muḥammad Muhȳī al-Dīn ibn 'Abd alHamīd and 'Abd al-Jalīl al-'Ațā al-Bakrī. Damascus: Maktabat Dār al-Fajr, 2001.

Ibn Hišām, 'Aw ḍaḥ = Jamāl al-Dīn 'Abū Muḥammad 'Abdallāh ibn Yūsuf ibn 'Aḥmad Ibn Hišām al-'Anșārī, 'Aw ḍah al-masālik 'ilā 'Alfiyyat Ibn Mālik. Ed. by H. al-Fāhūūī. 4 vols. Beirut: Dār al-Jīl, 1989 .

Ibn Jinnī, Haṣā'is = 'Abū l-Fatḥ 'Uțmān Ibn Jinnī al-Mawșilī, al-Hasạāiṣ. Ed. by 'Abd alHamīd Hindāwī. 3rd ed. 3 vols. Beirut: Dār al-Kutub al-'Tlmiyya, 2008.

Ibn Jinnī, Sirr = 'Abū l-Fatḥ 'Uțmān Ibn Jinnī al-Mawșilīi, Sirr șinā'at al-'írāb. Ed. by Muḥammad Ḥasan Muḥammad Ḥasan 'Ismāōil and 'Aḥmad Rušdī Šahāta 'Āmir. 2nd ed. 2 vols. Beirut: Dār al-Kutub al-'Ilmiyya, 2007.

Ibn Mālik, Šarh = 'Abū 'Abdallāh Jamāl al-Dīn Muhammad ibn 'Abdallāh ibn 'Abdallāh al-Ṭāī al-Jayyānī al-'Andalusī Ibn Mālik, Šarḥ al-Kāfiya al-Šāfiya. Ed. by 'Alī Muḥammad Mu'awwaḍ and 'Ādil 'Aḥmad 'Abd al-Mawjūd. 2nd ed. 2 vols. Beirut: Dār alKutub al-'Ilmiyya, 2010.

Ibn al-Najjār, Šarh = Muḥammad ibn 'Aḥmad ibn 'Abd al-'Azīz ibn 'Alī al-Fatawī alHanbalī al-ma'rūf bi-Ibn al-Najjār, Šarh al-Kawkab al-munīr. Ed. by Muhammad alZahịlī and Nazīh Ḥamād. 4 vols. Riyadh: Maktabat al-'Abīkān, 1993.

Ibn al-Sarrāj, 'Ușūl = 'Abū Bakr Muhammad ibn al-Sarī ibn Sahl Ibn al-Sarrāj al-Bag̉dādī, al-'Ușūl fì l-naḥw. Ed. by 'Abd al-Ḥusayn al-Fatlī. 3rd ed. 4 vols. Beirut: Mu’assasat alRisāla, 1996.

Ibn Sīda, Muhaṣṣaṣ = 'Abū l-Ḥasan 'Alī ibn 'Ismāc̄il al-Mursī al-Lugaawī al-Ḍarīr, alMuhașșaș. Cairo: Bulāq. (Repr., 17 vols. Beirut: Dār al-Kutub al-'Ilmiyya, s. d.)

Ibn 'Uṣfūr, Šarh = 'Abū l-Ḥasan 'Alī ibn al-Mu'min ibn Muḥammad al-Ḥaḍramī al-'Išbīlī Ibn 'Ușfūr, Šarh Jumal al-Zajjājī. Ed. by Fawwāz al-Ša'ār and 'Īmīl Badī' Ya'qūb. 3 vols. Beirut: Dār al-Kutub al-'Ilmiyya, 1998.

Ibn al-Warrāq, Ilal = 'Abū l-Ḥasan Muḥammad ibn 'Abdallāh ibn al-'Abbās Ibn alWarrāq, Tlal al-naḥw. Ed. by Maḥmūd Jāsim Muḥammad al-Darwīš. Riyadh: Maktabat al-Rušd, 1999.

\section{For use by the Author only | (C) 2018 Koninklijke Brill NV}


Ibn Yaīiš, Šarh = 'Abū l-Baqā’ Muwaffaq al-Dīn Yacīš ibn 'Alī Ibn Ya 'ī̌s al-'Asadī al-Ḥalabī, Šarh al-Mufașṣal li-l-Zamahšarī. Ed. by 'Imīl Badī‘ Ya`qūb. 2nd rev. ed. 6 vols. Beirut: Dār al-Kutub al-'Ilmiyya, 2011.

'İjīi, Šarh = 'Abū l-Faḍl 'Aḍud al-Dīn 'Abd al-Raḥmān ibn 'Aḥmad ibn 'Abd al-Ġaffār al-'Ījī', Šarḥ al-'Aụd 'alā Muhtaṣar al-Muntahā al-'uṣūlī. Ed. by Fādī Naṣîf and Ṭāriq Yaḥyā. Beirut: Dār al-Kutub al-'Tlmiyya, 2000.

Jurjānī, Šarh = 'Abū Bakr 'Abd al-Qāhir ibn 'Abd al-Raḥmān ibn Muḥammad al-Jurjānī, Šarḥ al-Jumal fí l-naḥw. Ed. by Hulīl 'Abd al-Qādir 'Īsā. 1oth ed. Beirut and Amman: Dār Ibn Ḥazm and al-Dār al-'Uțmāniyya, 2011.

Jurjānī, Muqtaṣid = 'Abū Bakr 'Abd al-Qāhir ibn 'Abd al-Raḥmān ibn Muḥammad alJurjān̄̄, al-Muqtașid fi šarh risālat al-'Ị̣̂āh. Ed. by al-Širbīnī Šarīda. 2 vols. Cairo: Dār al-Hadìt, 2009.

Juzūlī, Muqaddima = 'Abū Mūsā 'Īsā ibn 'Abd al-'Azīz ibn Yalalbaht al-Juzūlī al-Barbarī al-Marākiš̄i, al-Muqaddima al-juzūliyya fì l-naḥw. Ed. by 'Abd al-Wahhāb Muḥammad Ša'bān, Ḥāmid 'Aḥmad Nabīl, and Fatḥ̄ Muḥammad 'Aḥmad. Cairo: 'Umm al-Qurā, 1988.

Kafawī, Kulliyyāt = 'Abū l-Baqā' 'Ayyūb ibn Mūsā al-Ḥusaynī al-Kafawī, al-Kulliyyāt: Mujam fi l-muștalaḥāt wa-l-furūq al-luġawiyya. Ed. by 'Adnān Darwī̌̌ and Muḥammad al-Mișrī. Beirut: Mu’assasat al-Risāla.

Mubarrad, Muqtạ̣ab = 'Abū l-'Abbās Muḥammad ibn Yazīd ibn 'Abd al-'Akbar al-Timālī al-'Azadī al-Mubarrad, al-Muqtaḍa. Ed. by Ḥasan Hamad and 'Imīl Badī' Ya'qūb. 5 parts in 3 vols. Beirut: Dār al-Kutub al-'Ilmiyya, 1999.

Rāzī, Maḥsūl = Faḩr al-Dīn Muḥammad ibn 'Umar ibn al-Ḥusayn al-Rāzī, al-Mahṣūulfì 'ilm 'uṣūl al-fiqh. Ed. by Jābir Fayyāẹ al-'Alwānī. 3rd ed. 6 vols. Beirut: Mu’assasat alRisāla, 1997 .

Rummānī, Šarh = 'Abū l-Ḥasan 'Alī ibn 'Īsā ibn 'Alī al-Rummānī, Šarḥ Kitāb Sībawayhi. Ed. by Sayf ibn 'Abd al-Raḥmān ibn Nāṣir al-'Arīfì. Riyadh: Wizārat al-Ta'līm al-Ālī and Jāmi'at al-'Imām Muḥammad ibn Sa'ūd al-'Islāmiyya, 1998.

Šāfi'ì, Risāla = 'Abū 'Abdallāh Muḥammad ibn 'Idrīs al-Šāfi'ī al-Qurašī al-Muțtalibī, alRisāla. Ed. by 'Aḥmad Muḥammad Šākir. Beirut: Dār al-Kutub al-'Ilmiyya.

Sayyid al-Šarīf al-, Tárīfāt = 'Alī ibn Muḥammad ibn 'Alī al-Sayyid al-Šarīf al-Ḥusaynī alJurjānī al-Hanafì, al-Tárî́fāt. Ed. by Muḥammad Bāsil 'Uyūn al-Sūd. 2nd ed. Beirut: Dār al-Kutub al-'Ilmiyya. 2003.

Sībawayhi, Kitāb = 'Abū Bišr 'Amr ibn 'Uțmān ibn Qunbur Sībawayhi, al-Kitāb. Ed. by 'Imīl Badī' Ya'qūb. Beirut: Dār al-Kutub al-'Ilmiyya, 1999.

Sīrāfī, Šarḥ = 'Abū Sa'̄id al-Ḥasan ibn 'Abdallāh ibn al-Marzubān al-Sīrāfì, Šarḥ Kitāb Sïbawayhi. Ed. by 'Aḥmad Ḥasan Mahdalī and 'Alī Sayyid 'Alī. 5 vols. Beirut: Dār alKutub al-'Ilmiyya, 2008.

Suhaylī, Natā'ỉj = 'Abū l-Qāsim 'Abd al-Raḥmān ibn 'Abdallāh ibn 'Aḥmad al-Suhaylī alHațamī al-Mālaqī, Natāỉj al-fikr fì l-naḥw. Ed. by 'Ādil 'Aḥmad 'Abd al-Mawjūd and 'Alī Muḥammad Mu'awwaḍ. Beirut: Dār al-Kutub al-'Ilmiyya, 1992.

\section{For use by the Author only | (C) 2018 Koninklijke Brill NV}


Tacālibī, Figh al-luġa = 'Abū Manșūr 'Abd al-Malik ibn Muhammad ibn 'Ismāc̄il alTáālibī, Fiqh al-luġa wa-'asrār al-'arabiyya. Ed. by Yāsīn al-'Ayyūbī. 2nd ed. Saida and Beirut: al-Maktaba al-'Așriyya, 2000.

Zajjājī, Jumal = 'Abū l-Qāsim 'Abd al-Raḥmān ibn 'Isḥāq al-Nahāwandī al-Zajjājī, alJumal fì l-naḥw. Ed. by 'Alī Tawfĩq al-Ḥamad. 2 vols. Beirut and Irbid: Mu'assasat al-Risāla and Dār al-'Amal, 1984.

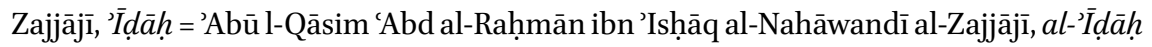
fi 'ilal al-naḥw. Ed. by Māzin al-Mubārak. 3rd ed. Beirut: Dār al-Nafāìs, 1979.

Zajjājī, Lāmāt = 'Abū l-Qāsim 'Abd al-Raḥmān ibn 'Isḥāq al-Nahāwandī al-Zajjājī, Kitāa al-lāmāt. Ed. by Māzin al-Mubārak. 2nd ed. Beirut: Dār Șādir, 1992.

Zamahšarī, Mufașșal = 'Abū l-Qāsim Maḥmūd ibn 'Umar ibn Muḥammad Jār Allāh al-Hawārizmī al-Zamahšarī, al-Mufașșal fi șan'at al-ìrāb. Ed. by 'Imīl Badī‘ Ya'qūb. Beirut: Dār al-Kutub al-'Ilmiyya, 1999.

Zarkašī, Tašnīf = Badr al-Dīn Muḥammad ibn Bahādir ibn 'Abdallāh al-Zarkašī, Tašnīf al-masāmi` bi-jam' al-jawāmi` li-Tāj al-Dīn al-Subkī. Ed. by Sayyid 'Abd al-'Azīz and 'Abdallāh Rabī'. 4 vols. Cairo and Mecca: Maktabat Qurțuba and Maktabat al-Malikiyya, 1998.

\section{B Secondary Sources}

'Abbās Ma'an, Muštāq. 2001. al-Mu'jam al-mufașșal fi fiqh al-lug̉a. Beirut: Dār al-Kutub al-'Ilmiyya.

'Abbās Ma'an, Muštāq. 2002. al-Mujam al-mufașșal fímuștalahāat fiqh al-luġa al-muqāran. Beirut: Dār al-Kutub al-'Ilmiyya.

Badī'Ya'qūb, 'Imīl and Mišāl ‘Āṣī. 1987. al-Mu jam al-mufașṣalfi-l-lug̉a wa-l-'adab. 2 vols. Beirut: Dār al-'Ilm li-l-Malāyīn.

Baraké, Bassam. 1985. Dictionnaire de linguistique avec un index alphabétique des termes arabes. Tripoli: Jarrouss Press.

Blachère, Régis. 1950. Le Coran. Paris: Maisonneuve.

Blachère, Régis, and Maurice Gaudefroy-Demombynes. 1975. Grammaire de l'arabe classique (morphologie et syntaxe). 3rd rev. ed. Paris: Maisonneuve et Larose.

Brustad, Kristen E. 200o. The syntax of spoken Arabic: A comparative study of Moroccan, Egyptian, Syrian and Kuwaiti dialects. Washington, D.C.: Georgetown University Press.

Carter, Michael G. 1981. Arab linguistics: An introductory classical text with translation and notes. Amsterdam: J. Benjamins.

Carter, Michael G. 200o. "Ta'rîf”. Encylopédie de l'Islam (EI2), ed. by Peri J. Bearman et al., X, 241a-b. Leiden: E.J. Brill.

Caspari, Carolus Paulus [Carl Paul]. 1848. Grammatica arabica in usum scholarum academicarum. Leipzig: C.L. Fritzsch. [German transl., Grammatik der arabischen Sprache für akademische Vorlesungen. 2nd rev. ed., Leipzig: C.L. Fritsch, 1859.] 
Chaumont, Éric. 2009. "Ambiguity". Encyclopaedia of Islam, Three, ed. by Denis Matringe, Gudrun Krämer, John Nawas, and Everett Rowson. Leiden: E.J. Brill. [Available at: http://referenceworks.brillonline.com.lama.univ-amu.fr/entries /encyclopaedia-of-islam-3/ambiguity-COM_23675].

Fawwāl Bābitī, 'Azīza. 1992. al-Mu'jam al-mufașșal fíl-naḥw al-'arabì. 2 vols. Beirut: Dār al-Kutub al-IImiyya.

Fleisch, Henri. 1961. Traité de philologie arabe. I. Préliminaires, phonétique, morphologie nominale. Beirut: Imprimerie catholique.

Fleisch, Henri. 1979. Traité de philologie arabe. II. Pronoms, morphologie verbale, particules. Beirut: Dar al-Machreq.

Fleisch, Henri. 1986. "İāfa". Encyclopaedia of Islam, second Edition, ed. by Bernard Lewis et al., III, 1008a-10o9a. Leiden: E.J. Brill.

Forbes, Duncan. 1863. Grammar of the Arabic language. London: Wm.H. Allen \& Co.

Gätje, Helmut. 1970. "Zum Begriff der Determination und Indetermination im Arabischen". Arabica 17.225-251.

Goguyer, Antonin. 1887. La pluie de rosée. Étanchement de la soif. Traité de flexion et de syntaxe par Ibnu Hijām. Leiden: E.J. Brill.

Goguyer, Antonin. 1995. La Alfyyah d'Ibnu-Malik, suivie de la Lāmiyyah et un lexique arabe-français des termes techniques. 2nd ed. Beirut: Librairie du Liban. (1st ed., 1888.)

Hilāl, Haytam. 2003. Mujam muștalaḥ al-'uṣūl. Beirut: Dār al-Jīl.

Howell, Mortimer Sloper 1911 [1880-1911]. A grammar of the Classical Arabic language. Translated and compiled from the works of the most approved native or naturalized authorities. 4 vols. Allahabad.

Hoyt, Frederick M. 2009. "Specificity". Encyclopedia of Arabic language and linguistics, ed. by Mushira Eid et al., IV, 315-320. Leiden: E.J. Brill.

Kinberg, Naphtali. 1996. A lexicon of al-Farrä's terminology in his Qur'ān commentary. Leiden: E.J. Brill.

Labdī, Muḥammad Samīr Najīb al- 1985. Mújam al-mușțalaḥāt al-naḥwiyya wa-l-ṣarfiyya. Beirut: Mu'assasat al-Risāla and Dār al-Furqān.

Larcher, Pierre. 1983. "Dérivation délocutive, grammaire arabe, grammaire arabisante et grammaire de l' arabe”. Arabica 30.246-266.

Larcher, Pierre. 1988. "Quand, en arabe, on parlait de l' arabe ...: Essai sur la méthodologie de l' histoire des 'métalangages arabes', I”. Arabica 35.117-142.

Larcher, Pierre. 199o. "Éléments pragmatiques dans la théorie grammaticale arabe post-classique". Studies in the history of Arabic grammar. II. Proceedings of the 2nd Symposium on the History of Arabic Grammar, Nijmegen, 27 April-1 May 1987, ed. by Michael G. Carter and Kees Versteegh, 195-214. Amsterdam and Philadelphia: J. Benjamins.

Larcher, Pierre. 1991. "Du mais français au lākin(na) arabe et retour: Fragment d'une histoire comparée de la linguistique”. Revue Québécoise de linguistique 20:1.171-193. 
Larcher, Pierre. 1992. "La particule lākinna vue par un grammairien arabe du XIII ${ }^{\mathrm{e}}$ siècle ou comment une description de détail s' inscrit dans une 'théorie pragmatique'". Historiographia Linguistica 19.1-24.

Larcher, Pierre. 1993. "Un grammairien 'retrouvé.' 'Abd al-Qāhir al-Ǧurǧān̄: Note sur quatre éditions récentes de ses ouvrages grammaticaux”. Arabica 40.248-253.

Larcher, Pierre. 1994. "Mā fáala vs lam yaf'al: Une hypothèse pragmatique". Arabica 41.388-415.

Larcher, Pierre. 1998. “Une pragmatique avant la pragmatique: 'Médiévale', 'arabe' et 'islamique'”. Histoire Épistémologie Langage 20:1.101-116.

Larcher, Pierre. 2014. Linguistique arabe et pragmatique. Beirut: Presses de l' Ifpo.

Layish, A. 1991. 'Mahkama-xiii. Reforms in the law applying in Sharī'a courts.' Encyclopédie de l'Islam (EI2), ed. by C. Edmund Bosworth et al., IV. 40a-42b. Leiden: E.J. Brill.

Lyons, Christopher. 1999. Definiteness. Cambridge: Cambridge University Press.

Marzā al-Huāmis, Yūḥannā 2012. Mawsūáat al-mușțalaḥ al-naḥwī. 2 vols. Beirut: Dār alKutub al-'Ilmiyya.

Muḥammad 'Alī 'Abd al-Raḥmān, 'Ismā'īl 2010. 'Ațar al-tahșị̂ṣ fì l-fiqh al-'islāmī. Riyadh. [Available at: www.riyadhalelm.com/researches/4/89w_athr_takhses.doc].

Murāgì̄, 'Abdallāh Muṣțafā al-. 1947. al-Fath al-mubīn fíṭabaqāt al-'uṣūliyyìna. 2 vol. s. l.: 'Anșār al-sunna al-ḥamdiyya.

Palmer, E.H. 1874. A grammar of the Arabic language. London: Wm.H. Allen \& Co.

Paret, Rudi. 1997. "Istihsān wa-Istiṣlāh". Encyclopaedia of Islam, Second Edition, ed. by Emery van Donzel et al., IV, 255b-259a. Leiden: E.J. Brill.

Reckendorf, Hermann. 1921. Arabische Syntax. Heidelberg: Carl Winter's Universitätsbuchhandlung.

Ryding, Karin C. and Kees Versteegh. 2007. "II āfa". Encyclopedia of Arabic language and linguistics, ed. by Mushira Eid et al., II, 294-298. Leiden: E.J. Brill.

Sānū, Quṭb Muṣțafā. 200o. Mu jam mușțalahāt 'uṣūl al-fiqh. Damascus: Dār al-Fikr.

Šaylahān̄̄, 'Umar ibn 'Abd al-'Azīz al-. 200o. Mabāhị al-tahșịṣ inda l-'uṣūliyyīna. Amman: Dār 'Usāma li-l-Našr wa-l-Tawzīc .

Silvestre de Sacy, Antoine-Isaac 1831. Grammaire arabe à l'usage des élèves de l'école spéciale des langues orientales vivantes. 2nd rev. ed. 2 vols. Paris: Imprimerie royale. (3rd ed., rev. by L. Machuel, Tunis: Institut de Carthage, 1904.)

Socin, Albert. 1885. Arabische Grammatik: Paradigmen, Litteratur, Chrestomathie und Glossar. Karlsruhe and Leipzig: Reuther.

Troupeau, Gérard. 1976. Lexique-index du Kitāb de Sïbawayhi. Paris: Klincksieck.

Troupeau, Gérard. 1993. "Na't”. Encyclopédie de l'Islam (EI2), ed. by C. Edmund Bosworth et al., viI, 1034a. Leiden: E.J. Brill.

'Ubāda, Muḥammad 'Ibrāhīm. 2011. Mucjam muștalaḥāt al-naḥw wa-l-ṣarf wa-l-'arūẹ wa-l-qāfiya. Cairo: Maktabat al-'Āēāb.

\section{For use by the Author only | (C) 2018 Koninklijke Brill NV}


Vernier, Donat. 1891. Grammaire arabe composée d'après les sources primitives. 2 vols. Beirut: Imprimerie catholique.

Versteegh, Kees. 2007. "Illa". Encyclopedia of Arabic language and linguistics, ed. by Mushira Eid et al., II, 308-311. Leiden: E.J. Brill.

Versteegh, Kees. 2011. "The term 'illa and the notion of causality in Arabic linguistics".

Orientalische Studien zu Sprache und Literatur: Festgabe zum 65. Geburtstag von Werner Diem, ed. by Ulrich Marzolph, 87-97. Wiesbaden: O. Harrassowitz.

Weiss, Bernard G. 1984. "Language and law: The linguistic premises of Islamic legal science". In quest of an Islamic humanism: Arabic and Islamic studies in memory of Mohamed al-Nowaihi, ed. by Arnold H. Green, 15-21. Cairo: s. p.

Weiss, Bernard G. 200o. "Umūm wa-khuṣūṣ". Encyclopédie de l'Islam (EI2), ed. by Peri J. Bearman et al., X, 366b-367a. Leiden: E.J. Brill.

Wright, William. 1896-1898. A grammar of the Arabic language. Translated from the German Caspari and edited with numerous additions and corrections. 3rd ed. rev. by W. Robertson Smith and M.J. de Goeje. 2 vols. Cambridge: Cambridge University Press. (Repr., Beirut: Librairie du Liban, 1996.) 